\title{
The Influence of Social Media on Consumer Purchase Intentions: Like Behavior as a Moderator
}

\author{
Mercyano Christi, Shellyana Junaedi \\ Universitas Atma Jaya Yogyakarta, Indonesia \\ Email: mercyanoc@gmail.com, and sheellyana.junaedi@uajy.ac.id
}

\begin{tabular}{|c|c|}
\hline ARTICLE INFO & ABSTRACT \\
\hline $\begin{array}{l}\text { Date received : } 01 \text { January } 2021 \\
\text { Revision date : } 05 \text { February } 2021 \\
\text { Date received : } 02 \text { March } 2021\end{array}$ & $\begin{array}{l}\text { his study aims to analyze the effect of e-WOM, brand } \\
\text { image, brand awareness on perceived value and } \\
\text { purchase intention with liking behavior as moderation. }\end{array}$ \\
\hline $\begin{array}{l}\text { Keywords: } \\
\text { E-Wom } \\
\text { Brand ImageBrand Image } \\
\text { Brand AwarenessBrand Awareness } \\
\text { Perception ValuePerceived Value } \\
\text { Liking BehaviorLiking Behavior } \\
\text { Media Sosial Social Media }\end{array}$ & $\begin{array}{l}\text { The object of this research is the Lactona brand on } \\
\text { social media. Valid respondents in this study amounted } \\
\text { to } 145 \text { respondents. Data were collected through an } \\
\text { online questionnaire. Consumers often use social } \\
\text { networking sites that are studied through electronic } \\
\text { word of mouth references, consumers can easily obtain } \\
\text { various types of brand information that drive purchase } \\
\text { intention. Based on the perspective of consumer } \\
\text { behavior, a research model was developed to determine } \\
\text { what factors influence consumer value perceptions and } \\
\text { purchase intentions on social media. Of all the variables, } \\
\text { only liking behavior is insignificant. The results of this } \\
\text { study can be used as a reference for further research on } \\
\text { research development. }\end{array}$ \\
\hline
\end{tabular}

\section{INTRODUCTION}

The social media network has become a powerful platform for connecting people as it allows virtual discussion and broadcast of all kinds of content on the Internet (Bauer, Stokburger-Sauer, \& Exler, 2008). Therefore, many companies do advertising activities on social media, one of which is using Instagram social media. Instagram has grown and become a worldwide favorite social media. In Indonesia, the number of Instagram social media users is growing. According to research from media company We Are Social \& Hootsuite., (2020) there are 63 million Instagram social media users in Indonesia. That number is up 10 million users compared to the research results in 2019. 49.2 percent of Instagram users were detected as male while 50.8 percent were women.

Social media is a new marketing tool that allows us to know new consumers as well as potential consumers in ways that were previously impossible (Karen, 2016).
Another social media that is very popular in Indonesia is Facebook. According to research from media company We Are Social \& Hootsuite (2020) there are 130 million social media users on Facebook. No wonder Facebook has been standing for quite a long time since 2004 compared to instagram social media that was established since 2010 (Santoso, 2017).

Lactona is an Indonesian dairy brand produced since 1973, experiencing significant changes in its promotional activities. Lactona is participating in the era of online marketing development through Instagram and Facebook.

The perception of consumer value towards Lactona has been established for a long time. The perceived value is related to consumer perception of the value of the product characterized by the performance and function considerations of the price of the goods and the level of emotional engagement (Chiang \& Tseng, 2017). Social media has an

\begin{tabular}{ll}
\hline How to cite: & $\begin{array}{l}\text { Christi, Mercyano. and Shellyana Junaedi. (2021) The Influence of Social Media on } \\
\text { Consumer Purchase Intentions: Like Behavior as a Moderator), 2(3). } \\
\text { https://doi.org/10.46799/jsss.v2i3.91 }\end{array}$ \\
\hline E-ISSN: & $2721-5202$ \\
\hline Published by: & Ridwan Institute \\
\hline
\end{tabular}


important role as a shaper of perception values and a means of communication to share information in order to connect with each other. Social media is used as a space to interact with people of various circles. For example Instagram and Facebook, many companies use to connect with consumers to convey information, search for consumer trends and wants, and build brand image and positive perception (Santoso, 2017).

Based on the research of (Jalilvand et al, 2011) stated that electronic word of mouth (e-WOM) on social media has a significant influence on consumers'

intention to make purchases. It is proven that the importance of brand image and positive e-WOM in the formation of perception value, so as to create consumer purchasing intentions on social media.

Related brand awareness where consumers are looking for information and are familiar with brand names and remembering, as well as recognizing those brands. Strong memories that consumers collect about a particular brand can be used as a basis for consideration when choosing a product (Chitcharoen, Kanthawongs, Wathanasuksiri, \& Kanthawongs, 2013). Lactona sees the rapid development of Instagram and Facebook to be able to maximize brand awareness to its consumers.

Like behavior is related to consumer motivation to like the content of photos or videos uploaded on social media. The phenomenon of liking behavior allows consumers to express their preferred attitude towards specific information and other people's responses on social media, by clicking likes (Gan, 2017).

The more people like content on social media, the higher the value of consumer perception and purchasing intentions (Chiang \& Tseng, 2017).

Therefore, the purpose of the research to be achieved is to know and obtain the results of research, namely:

1. Testing the influence of e-WOM on perception value

2. Testing the influence of brand image on perception value

3. Testing the influence of brand awareness on the value of perception

4. Testing the influence of brand awareness on purchasing intentions
5. Test the value of perception of buying intentions

6. Test the influence of liking behavior that moderates between perception value and purchase intention.

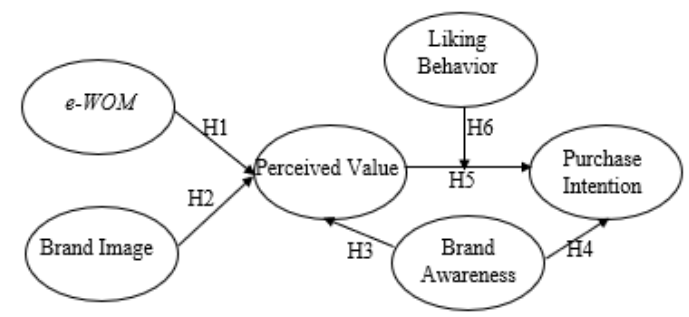

Figure 1.

Research Model

(Chiang \& Tseng, 2017: 48).

\section{METHOD}

The method in this study used purposive sampling. This method is a technique to determine research samples with certain considerations that aim to make the data obtained later can be more representative (Sugiyono, 2017).

The research was conducted by distributing questionnaires online to respondents. In this study, researchers determined the number of samples as many as 145 respondents. The criteria of respondents selected are individhu who have purchased Lactona brand products at least 1 time in the last 3 months with the age range of respondents are between the ages of 18 55 years, and are followers of Lactona social media. 
Respondent Profile

\begin{tabular}{|c|c|c|c|}
\hline $\begin{array}{c}\text { Characteristi } \\
\text { cs }\end{array}$ & Description & Number & $\%$ \\
\hline \multirow[t]{2}{*}{ Gender } & Male & 55 & $38 \%$ \\
\hline & Female & 90 & $62 \%$ \\
\hline \multirow[t]{6}{*}{ Age } & $20-25$ & 23 & $17 \%$ \\
\hline & $26-30$ & 31 & $12 \%$ \\
\hline & $30-35$ & 62 & $44 \%$ \\
\hline & $35-40$ & 27 & $21 \%$ \\
\hline & $41-45$ & 1 & $1 \%$ \\
\hline & $45-50$ & 1 & $1 \%$ \\
\hline \multirow[t]{4}{*}{ Job } & Student & 7 & $5 \%$ \\
\hline & Employees & 95 & $66 \%$ \\
\hline & Self employed & 25 & $17 \%$ \\
\hline & Housewives & 18 & $12 \%$ \\
\hline \multirow{5}{*}{$\begin{array}{l}\text { Expenses / } \\
\text { months }\end{array}$} & $<$ Rp 1.500 .000 & 8 & $6 \%$ \\
\hline & $\begin{array}{l}\text { Rp.1.500.001 - } \\
\text { Rp. } 2.500 .000\end{array}$ & 58 & $42 \%$ \\
\hline & $\begin{array}{l}\text { Rp. } 2.500 .001- \\
\text { Rp. } 3.500 .000\end{array}$ & 42 & $30 \%$ \\
\hline & $\begin{array}{l}\text { Rp. 3.500.001- } \\
\text { Rp. } 4.500 .000\end{array}$ & 16 & $12 \%$ \\
\hline & >Rp. 4.500 .000 & 15 & $11 \%$ \\
\hline \multirow{2}{*}{$\begin{array}{l}\text { Social media } \\
\text { followed }\end{array}$} & Instagram & 134 & $68 \%$ \\
\hline & Facebook & 64 & $32 \%$ \\
\hline
\end{tabular}

\section{RESULTS AND DISCUSSION}

Researchers used multiple regression analysis and SPSS software to process the data obtained. Here are the results of the first multiple regression

1. The Influence of e-WOM, Brand Image, and Brand Awareness on Perception Value

Table 2.

\section{Regression Result 1}

\begin{tabular}{|c|c|c|c|c|c|}
\hline $\begin{array}{l}\text { Independent } \\
\text { Variable }\end{array}$ & $\begin{array}{c}\text { Dependent } \\
\text { Variable }\end{array}$ & Beta & $\mathbf{t}$ & Sig & Result \\
\hline E-WOM & \multirow{3}{*}{$\begin{array}{l}\text { Perceived } \\
\text { Value }\end{array}$} & 0,320 & 3.816 & 0,000 & Significant \\
\hline Brand Image & & 0,309 & 3.328 & 0,001 & Significant \\
\hline Brand Awareness & & 0,185 & 2.243 & 0,026 & Significant \\
\hline \multicolumn{6}{|l|}{ Adj. Square $=0,509$} \\
\hline \multicolumn{6}{|l|}{ Prob/Sig. F $=0,000$} \\
\hline$F$ Count $=50,695$ & & & & & \\
\hline
\end{tabular}

From the data above, the result of the $F$ test can be obtained calculated $F$ value of 50.695 with a probability value of 0.000 indicating that the probability $(0.000)<0.05$. With the data it can be concluded that $\mathrm{Ho}$ is rejected and $\mathrm{Ha}$ is accepted i.e.e-WOM, brand image and brand awareness have a significant influence on the value of

perception. In other words, these three variables, namely e-WOM, brand image and brand awareness can increase the value of perception on Lactona social media. Judging from the data that has Adj. R-Square 0.509 which means that $50.9 \%$ of perception value is influenced by e-WOM, brand image and brand awareness, while the remaining $49.1 \%$ is influenced by other variables outside of this study.

H1: E-WOM positively and significantly affects the value of perception obtained from the test result $t$ in the variable e-WOM is the value of the regression coefficient (beta) of 0.320 with a probability $(p)$ of $0.000<0.05$, it can be concluded that e-WOM has a positive and significant influence on the value of perception. The results showed that eWOM has a positive and significant effect on the value of perception. The better e-WOM on Lactona social media will positively increase the value of perception felt by consumers. This is in line with research conducted by ( $\mathrm{Li}$ et $\mathrm{al}, 2012$ ) which states that e-WOM is a key element that influences consumer purchasing intentions and this is the strength of recommendations to others expressed in words. E-WOM represents the consumer's opinion of a product poured online through social media, the better opinion from consumers towards Lactona will be able to increase the positive perception of consumers towards the product.

$\mathrm{H} 2$ : Brand Image positively and significantly affects the value of perception.

Obtained from the test result of $t$ in Brand Image variable namely regression coefficient value (beta) of 0.309 with probability (p) $0.001<0.05$, it can be concluded that Brand Image has a positive and significant influence on perception value. The results showed that brand image has a positive and significant effect on the value of perception. The better brand image that consumers feel on Lactona social media will positively be able to increase the value of perception. According to (Chiang \& Tseng, (2017) explaining the value of perception is the overall consumer's assessment of the benefits of the product based on what they receive and what they provide. This makes the brand image of a product will have an impact on the perception felt by consumers. 
If the consumer's brand image towards the product is better, it will be able to make the perception of value felt by consumers. This is in line with research from (Djatmiko \& Pradana, 2016) which states that online consumers can determine their perception of brand image and value through experiences that can influence their buying intentions.

H3: Brand Awareness positively and significantly affects the value of perception Obtained from the results of $t$ test on Brand Awareness variable that is the value of regression coefficient (beta) of 0.185 with probability (p) $0.026<0.05$, it can be concluded that Brand Awareness has a positive and significant influence on the value of perception. The results showed that brand awareness has a positive and significant effect on the value of perception. The better brand awareness that consumers feel on Lactona social media will positively increase the value of perception. According to (Barreda, Bilgihan, Nusair, \& Okumus, 2016) that level of awareness is determined by consumer perception of a product brand, which can be formed using social networking sites. Thus, brand awareness felt by consumers will affect consumer perception of a product. The results of this study are in line with research conducted by (Chiang \& Tseng, 2017) which stated that brand awareness affects the value of perception in consumers.

\section{Table 3.}

\section{Regression Result 2}

\begin{tabular}{|l|l|l|l|l|l|}
\hline \multicolumn{1}{|c|}{$\begin{array}{c}\text { Independent } \\
\text { Variable }\end{array}$} & $\begin{array}{c}\text { Dependent } \\
\text { Variable }\end{array}$ & Beta & t & Sig & Result \\
\hline Brand Awareness & $\begin{array}{c}\text { Purchase } \\
\text { Intention }\end{array}$ & 0,453 & 5.840 & 0,000 & Significant \\
\cline { 1 - 5 } & 0,289 & 3.727 & 0,000 & Significant \\
\hline Perceived Value & Adj. Square $=0,434$ & & & \\
\hline Prob/Sig. F $=0,000$ & & & & \\
\hline F Count $=56,256$ & & & & \\
\end{tabular}

From the data above the $\mathrm{F}$ test result can be obtained calculated $F$ value of 56.256 with a probability value of 0.000 indicating that the probability $(0.000)<0.05$. With this data, it can be concluded that Ho was rejected and $\mathrm{Ha}$ accepted that brand awareness and perception value have a significant influence on purchasing intentions. In other words, both variables, namely brand awareness and perception value can increase purchasing intentions on Lactona products. Judging from the data that has Adj. R-Square 0.434 which means that $43.4 \%$ of buying intentions are influenced by brand awareness and perception value, while the remaining $56.6 \%$ are influenced by other variables outside of this study.

$\mathrm{H} 4$ : Brand Awareness positively and significantly affects Purchasing Intention Obtained from the results of $t$ test on Brand Awareness variable that is the value of regression coefficient (beta) of 0.453 with probability (p) $0.000<0.05$, it can be concluded that brand awareness has a positive and significant influence on purchasing intention. The results showed that brand awareness has a positive and significant effect on purchasing intentions. The better brand awareness that consumers feel on lactona social media will positively be able to increase purchasing intentions. According to Lee et $\mathrm{al}$, (2014) stated that brand awareness has been identified as a significant variable to create a value perception and buying intention. Brand awareness can be the basis for purchasing considerations that are prioritized for consumers. Consumers who have a strong brand awareness of a brand, will make a positive preference for the brand when the consumer needs a product.

H5: Perception Value positively and significantly affects Purchasing Intention Obtained from the test result $t$ in the variable Perception Value that is the value of the regression coefficient (beta) of 0.289 with a probability (p) of $0.000<0.05$, it can be concluded that the Value of Perception has a positive and significant influence on buying intentions. The results showed that the perception of value has a positive and significant effect on purchasing intentions. The better perception of value that consumers feel on Lactona social media will positively be able to increase purchasing intentions. According to (Chiang \& Tseng, 2017) states that the perceived value is related to consumer perception of the value of the product characterized by the performance and function considerations of the price of goods and the level of emotional engagement. A product that is perceived well by consumers has a higher chance than other alternative products. This is in line with $\left(\mathrm{Hu}_{\text {, }}\right.$ Huang, Zhong, Davison, \& Zhao, 2016) also mentions on social shopping sites and confirms that consumer perception of value positively affects buying intentions. 
Table 3

Regression Result 3

\begin{tabular}{|l|l|l|l|l|r|}
\hline \multicolumn{1}{|c|}{$\begin{array}{c}\text { Independent } \\
\text { Variable }\end{array}$} & $\begin{array}{c}\text { Dependent } \\
\text { Variable }\end{array}$ & Beta & t & Sig & Result \\
\hline Perceived Value & & .648 & 2.090 & .038 & \\
\hline Liking Behavior & Purchase & .828 & 2.480 & .014 & \\
\hline $\begin{array}{l}\text { Perceived Value * } \\
\text { Liking Behavior }\end{array}$ & Intention & -.524 & -.984 & .327 & $\begin{array}{c}\text { Not } \\
\text { Significr }\end{array}$ \\
\hline Adj. Square $=0,515$ & & & & & \\
\hline
\end{tabular}

Table 3 shows that adjusted R-Square value is 0.515 which means that the change in consumer purchasing intention variable is determined by the variable value of perception and liking behavior of $51.5 \%$ and the remaining $48.5 \%$ by other variables not included in this model. The moderation effect of liking behavior on the influence of perception value on purchasing intention shows a value of -0.524 with a significance value of $0.327(>0.05)$ which means that liking behavior does not strengthen the influence of perception value on consumer purchasing intentions significantly. Lactona's social media has not been able to amplify the influence of value perception on purchasing intentions. According to (Gan, 2017) phenomenon of liking behavior allows consumers to express their preferred attitude towards specific information and other people's responses on social media, by clicking on likes, then they contribute to the value of a content in the form of a total number of likes. Consumer liking behavior can be influenced by consumers' interest in content uploaded on social media. If the uploaded content is considered less attractive by consumers, it will reduce the liking behavior of consumers. Another contributing factor is that liking behavior does not moderate the influence of perception on buying intentions on lactona social media, because Lactona's social media is new, it is evident from the followers of social media who are still few. This is not in line with previous research conducted by (Chiang \& Tseng, 2017) revealed the behavior of clicking likes as variable moderation beaked positively towards the value of perception and buying intentions.

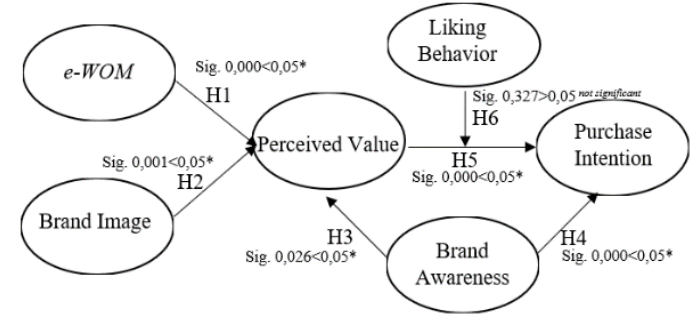

Figure 2.

Research Results

\section{CONCLUSION}

The results of the first study, e-WOM, brand image and brand awareness have a positive and significant effect on the perceived value of consumers. Then the results of the second study, brand awareness and perceived value have a significant and positive influence on purchase intention. Therefore the company is expected to be able to create a more informative content strategy that reviews product knowledge and excellence in social media in order to increase e-WOM, brand image, brand awareness and perceived value in society, thereby increasing consumer purchase intentions. Then the results of the third study, liking behavior cannot moderate the effect of perceived value on purchase intention, it is evident in Instagram's new policy that Instagram has reasons to hide the number of likes, reduce anxiety and reduce social comparisons (CNN Business, 2019). Thus companies can focus more on interesting and informative content strategies to upload on social media.

\section{REFERENCES}

Barreda, Albert A., Bilgihan, Anil, Nusair, Khaldoon, \& Okumus, Fevzi. (2016). Online branding: Development of hotel branding through interactivity theory. Tourism Management, 57, 180-192. Google Scholar

Bauer, Hans H., Stokburger-Sauer, Nicola E., \& Exler, Stefanie. (2008). Brand image and fan loyalty in professional team sport: A refined model and empirical assessment. Journal of Sport Management, 22(2), 205-226. Google Scholar

CNN, Business. (2019). Instagram is now testing hiding likes worldwide. Retrieved from 
https://edition.cnn.com/2019/11/14/tec $\mathrm{h}$ /instagram-hiding-

likesglobally/index.html. Google Scholar

Chiang, Chi Hui, \& Tseng, Kuo Chang. (2017). The influence of fan pages on consumer purchase intention: Liking behavior as a moderator. Journal of Marketing Management, 5(2), 44-59. Google Scholar

Chitcharoen, Chaisak, Kanthawongs, Penjuree, Wathanasuksiri, Kanokorn, \& Kanthawongs, Penjira. (2013). A model to investigate the influence of channel, perceived web quality, brand awareness, perceived quality on aftersales service of the all-in-one office products. Procedia-Social and Behavioral Sciences, 88, 8-12. Google Scholar

Djatmiko, Tjahjono, \& Pradana, Rezza. (2016). Brand image and product price; Its impact for Samsung smartphone purchasing decision. Procedia-Social and Behavioral Sciences, 219, 221-227. Google Scholar

Gan, Chunmei. (2017). Understanding WeChat users' liking behavior: An empirical study in China. Computers in Human Behavior, 68, 30-39. Google Scholar

$\mathrm{Hu}$, Xi, Huang, Qian, Zhong, Xuepan, Davison, Robert M., \& Zhao, Dingtao. (2016). The influence of peer characteristics and technical features of a social shopping website on a consumer's purchase intention. International Journal of Information Management, 36(6), 1218-1230. Google

\section{$\underline{\text { Scholar }}$}

Jalilvand, Mohammad Reza, Esfahani, Sharif Shekarchizadeh, \& Samiei, Neda. (2011). Electronic word-of-mouth: Challenges and opportunities. Procedia Computer Science, 3, 42-46. Google $\underline{\text { Scholar }}$

Karen, Kartika Tirtabudi. (2016). Penerapan Facebook Page Sebagai Alat Promosi Di Burgundy Dine \& Wine. Google Scholar

Lee, Maria R., Yen, David C., \& Hsiao, C. Y. (2014). Understanding the perceived community value of Facebook users. Computers in Human Behavior, 35, 350358. Google Scholar

Li, Guoxin, Li, Guofeng, \& Kambele, Zephaniah. (2012). Luxury fashion brand consumers in China: Perceived value, fashion lifestyle, and willingness to pay. Journal of Business Research, 65(10), 1516-1522. Google Scholar

Mirota id. (2020). History of Lactona. Retrieved from https://mirota.id/history/. Google Scholar

Santoso, Amanda Putri. (2017). Pengaruh konten post instagram terhadap online engagement: Studi kasus pada lima merek pakaian wanita. Institut Teknologi Sepuluh Nopember. Google Scholar

Sugiyono. (2017). Metode Penelitian Kombinasi (Mixed Methods). Bandung: Alfabeta. Google Scholar 